\title{
Using translational in vitro-in vivo modeling to improve drug repurposing outcomes for inhaled COVID-19 therapeutics
}

\author{
Authors: Madison Stoddard§ ${ }^{1}$, Lin Yuan ${ }^{1}$, Arijit Chakravarty ${ }^{1}$ \\ Affiliations: \\ ${ }^{1}$ Fractal Therapeutics Inc, Cambridge, MA, USA \\ § Corresponding author: madison.stoddard@fractaltx.com
}

\begin{abstract}
The ongoing COVID-19 pandemic has created an urgent need for antiviral treatments that can be deployed rapidly. Drug repurposing represents a promising means of achieving this objective, but repurposing efforts are often unsuccessful. A common hurdle to effective drug repurposing is a failure to achieve a sufficient therapeutic window in the new indication. A clear example is the use of ivermectin in COVID-19, where the approved dose (administered orally) fails to achieve therapeutic concentrations in the lungs. Our proposed solution to the problem of ineffective drug repurposing for COVID-19 antivirals is two-fold: to broaden the therapeutic window by reformulating therapeutics for the pulmonary route, and to select drug repurposing candidates based on their model-predicted therapeutic index for inhalation. In this article, we propose a two-stage model-driven screening and validation process for selecting inhaled antiviral drug repurposing candidates. While we have applied this approach in the specific context of COVID-19, this in vitro-in vivo translational methodology is also broadly applicable to repurposing drugs for diseases of the lower respiratory tract.
\end{abstract}

\section{Introduction}

One year into the COVID-19 pandemic, significant progress has been made in reducing mortality due to the disease, but options for effective treatments are still extremely limited. A particular gap in the therapeutic lineup exists for early treatments, leaving watchful waiting as the paradigm for outpatient care for the disease at present [1], despite evidence that early therapeutic intervention for COVID-19 is effective [2].

Drug repurposing is a somewhat obvious strategy for rapidly expanding the range of therapeutic options for COVID-19, as it is a fast, cheap and proven methodology. Over the past decade, for example, approximately one third of all new Food and Drug Administration (FDA) approvals have originated from repurposing studies [3,4]. Accordingly, antiviral drug repurposing in the context of the COVID-19 pandemic has garnered significant attention and funding. A variety of candidate identification techniques have been pursued, including in silico conformational docking studies [5,6], brute force in vitro screening of vast libraries [7], and protein-protein interaction network analysis [8]. As a result, a wealth of in vitro candidate validation data is available, and some of these drugs have already been tested in COVID-19 patients. 
medRxiv preprint doi: https://doi.org/10.1101/2021.03.11.21253375; this version posted March 12, 2021. The copyright holder for this preprint (which was not certified by peer review) is the author/funder, who has granted medRxiv a license to display the preprint in perpetuity. It is made available under a CC-BY-NC 4.0 International license .

Despite promising preclinical data and biological rationales, most of these drug repurposing efforts have met with limited clinical success, at best. For example, Remdesivir appears to confer a benefit in terms of reduced time-to-recovery, but the reduction in mortality is debatable at best [9]. As another example, hydroxychloroquine yielded no clinical benefit in large-scale clinical trials, either alone or in combination with azithromycin [10]. A third drug combination identified through repurposing efforts, lopinavir combined with ritonavir, has not been found to reduce mortality or fraction of patients with detectable viral RNA among hospitalized patients [11]. As a fourth example, ivermectin, which showed promising in vitro efficacy, has demonstrated marginal clinically efficacy when dosed orally [12]. Consistent with this disappointing performance in the clinic, translational modeling for ivermectin predicts insufficient exposure in the lungs under the clinically-approved oral regimen [13].

It is likely that this failure to achieve sufficient concentrations in the lungs represents a common mode of failure for systemically-dosed antivirals for COVID-19. SARS-CoV-2 infections are thought to be seeded in the upper respiratory tract, with viral particles making their way to the lungs as the disease progresses [14], and attendant lung damage is a common etiological and pathological factor for full-blown COVID-19. Therapeutic interventions that disrupt viral proliferation in the lungs thus hold the potential to impact the trajectory of the clinical disease in patients.

Despite the early failures for COVID-19, drug repurposing remains the best path forward for rapidly expanding treatment options for this disease. For other viral diseases, this approach has been effective- for example, repurposed nitazoxanide, an antiviral in extensive use for other respiratory pathogens, was found to significantly reduce the duration of influenza symptoms and reduce viral titer by 10 -fold [15].

Local administration is an elegant solution to the problem of a narrow therapeutic window. For respiratory diseases affecting the lungs, inhaler- or nebulizer-administered therapies represent a safe and efficient means of delivering drug to the active site [16]. Many well-characterized technologies are already available for drug inhalation, and some antiviral drugs are already administered through this route [17]. Recent publications have proposed the pulmonary route as a repurposing strategy for COVID-19, focusing on drugs with prior clinical data via the pulmonary route [18] or assessing lung concentrations for therapeutics administered via the approved systemic routes [19].

In this work, we have sought to extend this framework further by asking the question: "are there drugs for which a pulmonary route represents a viable clinical strategy, with reformulation if necessary?" To answer this question, we have developed a two-stage model-based screening platform to identify promising candidates among in vitro-validated drugs which have undergone clinical testing for another indication. In the first stage, we employ a rapid computational screen to select in vitro-characterized drugs likely to exhibit a high therapeutic index (TI) in the inhaled setting, including both approved drugs with prior clinical experience via the pulmonary route and drugs for which the pulmonary route would require reformulation and redevelopment. Next, we built a computational deposition-PK model to refine the therapeutic index calculation for candidates predicted to have a wide $\mathrm{TI}$ and provide preliminary lung kinetics estimates. This two-step process provides in silico proof-of-concept for a pulmonary delivery approach and supports the rational design of dosing regimens in the new indication. Such an approach allows us to increase the likelihood of achieving therapeutic drug concentrations for COVID-19 treatment while avoiding dose-limiting toxicity. 
medRxiv preprint doi: https://doi.org/10.1101/2021.03.11.21253375; this version posted March 12, 2021. The copyright holder for this preprint (which was not certified by peer review) is the author/funder, who has granted medRxiv a license to display the preprint in perpetuity.

\section{Methods}

\section{Rapid drug screen based on estimated therapeutic index}

We propose a two-stage repurposed drug screening and in silico validation process based on maximizing $\mathrm{Tl}$ for inhalation. The purpose of the first stage is to rapidly screen a large number of repurposing candidates for likely large TI. This screening process is summarized in Figure 1.

Repurposing candidates with clinical precedent as inhaled therapeutics is the most desirable approach as in this case the maximum tolerated dose (MTD) via the inhalation route is known. However, repurposing candidates lacking clinical precedent as inhaled therapeutics can be evaluated on the basis of systemic toxicity. We have outlined both approaches. For the purpose of this screen, all repurposing candidates must have in vitro antiviral activity data yielding an $\mathrm{EC}_{90}\left(90 \%\right.$ maximal effective concentration). Commonly, $\mathrm{EC}_{50}$ (half-maximal effective concentration) values are reported in the literature. The $\mathrm{EC}_{90}$ is preferably estimated from the in vitro dose-response curve, but may also be estimated using the following equation:

$$
E C_{90}=9 * E C_{50}
$$

This relation assumes a Hill coefficient of 1 . A Hill coefficient of 1 is typical for a small molecule that binds a target with a single binding site without cooperativity [20]. However, some antivirals may exhibit distinct binding and potency properties, so estimating the $\mathrm{EC}_{90}$ based on in vitro data will yield a more accurate result.

Based on the $\mathrm{EC}_{90}$, a simple therapeutic index $(\mathrm{TI})$ calculation can be performed based on the highest known tolerated dose. If the MTD for the inhaled setting is available, the following local TI calculation can be made:

$$
\text { Local TI }=\frac{\text { Inhaled MTD }}{E C_{90} \times \text { Lung fluid volume }}
$$

This preliminary $\mathrm{TI}$ calculation represents the ratio of the expected lung concentration at the inhaled MTD to the experimental EC $\mathrm{E}_{90}$. The fluid volume of the lungs is approximately $25 \mathrm{~mL}$ [21]. For the purpose of this calculation, we assumed that all administered drug reaches the lung (perfect deposition). This is optimistic but suitable for a preliminary screen. The extent of deposition is refined in the candidate validation stage.

If clinical toxicity data for inhalation is not available for a candidate drug, a systemic TI can be estimated based on the systemic MTD and peak plasma concentration $\left(C_{\max }\right)$. This calculation is as follows:

$$
\text { Systemic TI }=\frac{C_{\text {max }} \text { at MTD } \times V_{D}}{E C_{90} \times \text { Lung fluid volume }}
$$

where $V_{D}$ represents the plasma volume of distribution. We note that for a drug administered by IV bolus, the $C_{\max }$ at MTD multiplied by $V_{D}$ is equivalent to the MTD. This calculation ensures 
medRxiv preprint doi: https://doi.org/10.1101/2021.03.11.21253375; this version posted March 12, 2021. The copyright holder for this preprint (which was not certified by peer review) is the author/funder, who has granted medRxiv a license to display the preprint in perpetuity.

It is made available under a CC-BY-NC 4.0 International license .

that the estimated inhaled therapeutic dose would not cause intolerable systemic toxicity assuming that the drug transits instantaneously from the lungs to systemic circulation. This is a pessimistic assumption but covers the potential for highly rapid absorption from the lungs [22].

Candidate validation and go/no-go based on lung deposition-pharmacokinetic model

The second stage of the drug repurposing platform refines the therapeutic index calculation and provides a preliminary lung pharmacokinetic model. In this stage, we estimated the fractional lung deposition of drug particles administered via the pulmonary route, for a number of different candidate inhalation devices (nebulizers and inhalers), converted this fractional deposition into a bolus or rate of drug entry into the lungs, and built a simple compartmental PK model to predict the concentration of drug in the lungs over time. This allows us to estimate the therapeutic dose required to achieve the $\mathrm{EC}_{90}$ in the lungs. The ratio of the inhaled maximum tolerated dose to the predicted therapeutic dose is the model-based refined local TI. We used this more timeintensive method to verify promising drug repurposing candidates with a wide TI. This process is outlined in Figure 2.

For some candidate drugs, lung deposition data based on prior clinical studies may be available. Where possible, we have leveraged this data. In the absence of clinical data, we estimate lung deposition based on the known particle distribution of the intended inhalation device and the known fraction of particles reaching the lungs based on their size. Computational fluid dynamics simulation of lung deposition represents a high-fidelity alternative which is outside the scope of this paper [23].

In this text, we have used ribavirin as an example candidate for repurposing in COVID-19. Under its current FDA approval, ribavirin is administered by Small Particle Aerosol Generator (SPAG-2) at a concentration of $20 \mathrm{mg} / \mathrm{mL}$ [24]. The SPAG-2's particle size distribution is wellcharacterized [25]. We used the known relationship between particle size and fractional deposition in the alveolae and bronchi to estimate the fraction by mass of each particle size bin in the SPAG-2 emission distribution that reaches the lungs [26]. The data for the SPAG-2 nebulizer is summarized in Table 1. We summed over the particle size distribution bins to determine the total fractional mass reaching the lungs. Autopsy studies have demonstrated direct viral cytopathic effect in both the alveolae and the bronchi, indicating the relevance of both sites [27].

Table 1. Data for estimating fractional lung deposition of SPAG-2 nebulizer.

\begin{tabular}{|c|c|c|c|}
\hline $\begin{array}{c}\text { Particle diameter } \\
\text { (um) }\end{array}$ & $\begin{array}{c}\text { \% of emission by } \\
\text { mass }\end{array}$ & $\begin{array}{c}\text { \% bronchial } \\
\text { deposition }\end{array}$ & $\begin{array}{c}\text { \% alveolar } \\
\text { deposition }\end{array}$ \\
\hline$>9$ & 2 & 15 & 1 \\
\hline $5.8-9$ & 0.6 & 29 & 4 \\
\hline $4.7-5.8$ & 0.9 & 34 & 23 \\
\hline $3.3-4.7$ & 4.8 & 30 & 32 \\
\hline $2.1-3.3$ & 16.4 & 19 & 39 \\
\hline $1.1-2.1$ & 22.4 & 8 & 35 \\
\hline $0.7-1.1$ & 20.4 & 3 & 23 \\
\hline $0.4-0.7$ & 18.2 & 2 & 13 \\
\hline$<0.4$ & 14.2 & 2 & 11 \\
\hline
\end{tabular}


medRxiv preprint doi: https://doi.org/10.1101/2021.03.11.21253375; this version posted March 12, 2021. The copyright holder for this preprint (which was not certified by peer review) is the author/funder, who has granted medRxiv a license to display the preprint in perpetuity.

It is made available under a CC-BY-NC 4.0 International license .

The lung deposition model serves as the drug input to the lung compartmental PK model. For a nebulized formulation, we determined the rate of drug entry into the lungs and treated this as a zero-order input over the administration duration. For formulations delivered by inhaler, the bolus dose reaching the lungs is treated as the initial condition and is calculated as the total dose multiplied by the fraction of drug deposited in the lungs. For nebulized drugs, we calculated the rate of drug entry as follows:

\section{Lung deposition rate}

$$
=\text { Nebulizer output rate } \times \text { Drug concentration } \times \text { Lung deposition fraction }
$$

For ribavirin, the output rate of the SPAG-2 nebulizer is $12 \mathrm{~mL} / \mathrm{hr}$ [25], and in the FDA-approved regimen, a concentration of $20 \mathrm{mg} / \mathrm{mL}$ is administered [24].

The lung PK model is comprised of a single compartment representing the lungs. We chose a one-compartment model for the general case because for most drugs, insufficient data is available to support a more complex model. The model accounts for the input of drug from the nebulizer or inhaler and the first-order loss of drug from the lungs through metabolic breakdown or absorption to systemic circulation. For most drugs, metabolic breakdown in the lungs is minimal relative to the rate of absorption to systemic circulation [28]. We assume that the deposited drug distributes instantaneously into the lung fluid volume of $25 \mathrm{~mL}$ [21]. The onecompartment model is described by the following ordinary differential equation (ODE):

$$
\frac{d C_{\text {lung }}}{d t}=\frac{\text { deposition rate }}{V_{d, \text { lung }}}-k_{a b s} C_{\text {lung }}
$$

where $\mathrm{C}_{\text {lung }}$ is the concentration of drug in the lung, $\mathrm{V}_{\mathrm{d} \text {, lung }}$ is the lung fluid volume, and $\mathrm{k}_{\mathrm{abs}}$ is the rate of drug clearance from the lung. For drugs administered by inhaler, the drug reaches the lungs as a bolus. In this case, the deposition rate is set to zero and the following initial condition is set:

$$
C_{\text {lung }}(t=0)=\frac{\text { Dose } \times \text { Lung deposition fraction }}{V_{d, \text { lung }}}
$$

For some drugs, the half-life in the lungs or the rate of absorption to systemic circulation is known from human pharmacokinetic studies. To predict the lung PK of ribavirin, we have relied on literature estimates for the rate of drug clearance from the lungs. Based on prior PK studies, the half-life of ribavirin in the lungs is 2 hours [29]. In the absence of such data, we estimated the rate of absorption based on Caco2 or Calu3 permeability reported in the literature [30]. The absorption rate can be estimated by multiplying the flux across the Caco2 cell monolayer by the surface area of the lungs [31]. The surface area of the adult human lungs is estimated to be 70 $\mathrm{m}^{2}[21]$.

This combined deposition-lung PK modeling framework allows translation of in vitro effective concentrations to in vivo predicted therapeutic doses. Determining effective dose requires knowledge of the PK driver of efficacy for antivirals. Commonly, peak concentrations at the active site $\left(\mathrm{C}_{\max }\right)$ or trough concentrations between doses $\left(\mathrm{C}_{\min }\right)$ have been found to drive efficacy of antivirals $[32,33]$. Conservatively, we have set $\mathrm{C}_{\min } \geq \mathrm{EC}_{90}$ as the constraint for the effective dose. This reduces the likelihood that subtherapeutic exposure will permit evolved 
medRxiv preprint doi: https://doi.org/10.1101/2021.03.11.21253375; this version posted March 12, 2021. The copyright holder for this preprint (which was not certified by peer review) is the author/funder, who has granted medRxiv a license to display the preprint in perpetuity.

It is made available under a CC-BY-NC 4.0 International license .

resistance in the lungs [34]. Depending on practical constraints, once-daily or multiple daily administrations may be feasible. Thus, the dosing schedule and dose may both be optimized to achieve effective concentrations. Once the total daily effective dose for a given schedule has been determined, the refined local TI can be calculated as the ratio of the daily MTD to the effective dose.

\section{Results}

Many systemically administered repurposed drugs are likely to face narrow TIs for COVID-19 Consistent with work done by others [35], we note that therapeutically active systemic concentrations are not achieved for many COVID-19 repurposing candidates after oral or intravenous administration (Table 2). This is indicated by a systemic administration TI less than 1 (for example, ribavirin and azithromycin). For many other candidate drugs, the $\mathrm{Tl}$ is near 1 , indicating little room for translation error or higher dosing to achieve therapeutic concentrations for a longer duration (for example, teicoplanin and indomethacin). The ability to achieve effective concentrations at the MTD is a significant constraint for systemically administered COVID-19 repurposing candidates.

Table 2: Feasibility of achieving $\mathrm{EC}_{90}$ by systemic administration.

\begin{tabular}{|c|c|c|c|}
\hline Drug & $\begin{array}{l}\text { Plasma } \mathrm{C}_{\max } \text { at MTD } \\
(\mu \mathrm{M})\end{array}$ & EC90 $(\mu \mathrm{M})$ & $\begin{array}{l}\text { Systemic } \\
\text { administration } \mathrm{TI}\end{array}$ \\
\hline Aprotinin & $250 \mathrm{KIU} / \mathrm{mL}^{*}[36]$ & $250 \mathrm{KIU} / \mathrm{mL}[37]$ & 1 \\
\hline Camostat & $0.2[38]$ & $5[39]$ & 0.034 \\
\hline Indomethacin & $5.6[40]$ & $3.8[41]$ & 1.47 \\
\hline Teicoplanin & 58.5 [42] & $50[43]$ & 1.17 \\
\hline Niclosamide & $2[44]$ & $1.2[45]$ & 1.67 \\
\hline Azithromycin & $0.7[46]$ & 8.7 [47] & 0.077 \\
\hline Ribavirin & $11.3[48]$ & 304 [9] & 0.037 \\
\hline Dipyridamole & 7 [49] & $4.8[50]$ & 1.46 \\
\hline
\end{tabular}

${ }^{*}$ Aprotinin is measured in kallikrein inhibitor units (KIU).

Ciclesonide is excluded from this analysis because administration is almost exclusively by inhaler.

Systemic toxicity is expected to be significantly reduced by local inhaled administration Although a wide range of Tls are predicted by our simple metric for systemic tolerability after inhalation, all Tls predicted are larger than 10 (Table 3). This indicates that systemic toxicity is unlikely to be a constraint for any of these drug candidates if administered by inhalation in COVID-19 patients. Notably, the therapeutic indices for inhalation for each drug are much wider than the corresponding indices for systemic administration (Table 2). This emphasizes the importance of local administration in drug repurposing for COVID-19.

Table 3: Systemic toxicity TI for COVID-19 repurposing candidates.

\begin{tabular}{|l|l|l|l|l|}
\hline Drug & MTD plasma $_{\max }(\boldsymbol{\mu M})$ & Plasma $_{\mathbf{D}}(\mathrm{L})$ & EC90 $(\mu \mathrm{M})$ & Systemic toxicity TI \\
\hline Aprotinin & $250 \mathrm{KIU} / \mathrm{mL}^{*}[36]$ & $26.5[51]$ & $250 \mathrm{KIU} / \mathrm{mL}[37]$ & 1,060 \\
\hline Camostat & $0.2[38]$ & $30.4[38]$ & $5[39]$ & 41 \\
\hline Indomethacin & $5.6[40]$ & $27.2[52]$ & $3.8[41]$ & 1,600 \\
\hline
\end{tabular}


medRxiv preprint doi: https://doi.org/10.1101/2021.03.11.21253375; this version posted March 12, 2021. The copyright holder for this preprint (which was not certified by peer review) is the author/funder, who has granted medRxiv a license to display the preprint in perpetuity.

It is made available under a CC-BY-NC 4.0 International license .

\begin{tabular}{|l|l|l|l|l|}
\hline Teicoplanin & $58.5[42]$ & $4.6[53]$ & $50[43]$ & 262 \\
\hline Azithromycin & $0.7[46]$ & $1,840[54]$ & $1.2[47]$ & 5,650 \\
\hline Ribavirin & $11.3[48]$ & $2,000[55]$ & $8.7[9]$ & 2,960 \\
\hline Dipyridamole & $7[49]$ & $92[56]$ & $4.8[50]$ & 5,370 \\
\hline Ciclesonide & $0.0025[57]$ & $9,800[58]$ & $6.3[59]$ & 157 \\
\hline
\end{tabular}

${ }^{*}$ Aprotinin is measured in kallikrein inhibitor units (KIU).

Limited PK data is available for niclosamide, so the systemic toxicity TI calculation was not performed.

For most drugs studied, tolerability after local administration allows a wide $\mathrm{TI}$

In Table 4, we calculated therapeutic indices based on local tolerability (MTD for inhaler- or nebulizer-administered formulations) for 9 drugs for which a dose-tolerability data was available in the context of inhalation. All drugs studied appear suitable for inhaled or nebulized administration in COVID-19 with the exception of aprotinin, which is not expected to reach therapeutic concentrations in the lungs at the highest tolerated inhaled dose.

Table 4: Local toxicity TI.

\begin{tabular}{|l|l|l|l|}
\hline Drug & Inhaled MTD $(\mathbf{m g}$ per day) & EC90 $(\boldsymbol{\mu M})$ & Local toxicity TI \\
\hline Aprotinin & $160 \mathrm{KIU}^{*}[60]$ & $250 \mathrm{KIU} / \mathrm{mL}[37]$ & 0.026 \\
\hline Camostat & $1.6[61]$ & $5[39]$ & 26 \\
\hline Indomethacin & $50[62]$ & $3.8[41]$ & 1,470 \\
\hline Teicoplanin & $200[63]$ & $50[43]$ & 85 \\
\hline Niclosamide & $50.5[64]$ & $1.2[45]$ & 5,130 \\
\hline Azithromycin & $70[65]$ & $8.7[47]$ & 430 \\
\hline Ribavirin & $6,000[66]$ & $304[9]$ & 3,240 \\
\hline Dipyridamole & $50[67]$ & $4.8[50]$ & 825 \\
\hline Ciclesonide & $2.88[68]$ & $6.3[59]$ & 34 \\
\hline
\end{tabular}

${ }^{*}$ Aprotinin is measured in kallikrein inhibitor units (KIU).

We also note that for most drugs studied, the MTD for local administration is a more significant constraint than the highest tolerated plasma $\mathrm{C}_{\max }$ (for either local or systemic delivery, whichever is higher). Thus, the availability of clinical data for inhalation is highly desirable for estimating the therapeutic window. This also justifies the choice to limit PK prediction in the validation step to the lungs rather than attempting to predict plasma concentrations after inhalation.

\section{Refined local TI calculation based on deposition-PK model}

To demonstrate the validation process, we calculated a more precise TI for ribavirin, a clinically approved antiviral drug proposed for repurposing in COVID-19. First, we estimated the fractional deposition in the lung based on the data summarized in Table 1. Based on this data, we estimated total lung deposition to be $33.1 \%$ of the total nebulized dose, with $8.4 \%$ of the dose deposited in the bronchial space and $24.7 \%$ deposited in the alveolae.

Our objective was to maintain ribavirin concentrations in the lungs above the $\mathrm{EC}_{90}$ at all times $\left(\mathrm{C}_{\min } \geq \mathrm{EC}_{90}\right)$. Total dose and dosing schedule are both determinants of $\mathrm{C}_{\min }$, so we tested three 
medRxiv preprint doi: https://doi.org/10.1101/2021.03.11.21253375; this version posted March 12, 2021. The copyright holder for this preprint (which was not certified by peer review) is the author/funder, who has granted medRxiv a license to display the preprint in perpetuity.

It is made available under a CC-BY-NC 4.0 International license .

possible administration schedules: daily (Figure 3A), twice-daily (BID, Figure 3B), and three times daily (TID, Figure 3C). These figures show the concentration-time profile in the lungs for a ribavirin regimen where the nebulized concentration is $20 \mathrm{mg} / \mathrm{mL}$ (consistent with the approved regimen) and the duration of nebulization is set to the shortest duration for which $\mathrm{C}_{\min } \geq \mathrm{EC}_{90}$. Table 5 summarizes the parameters and Tls of these three possible regimens.

Table 5. Comparison of possible ribavirin administration regimens.

\begin{tabular}{|c|c|c|c|}
\hline $\begin{array}{c}\text { Number of sessions } \\
\text { daily }\end{array}$ & $\begin{array}{c}\text { Duration of each } \\
\text { session (hrs) }\end{array}$ & $\begin{array}{c}\text { Total dose } \\
\text { administered (mg) }\end{array}$ & TI \\
\hline 1 & 9.2 & 2,208 & 2.72 \\
\hline 2 & 1.2 & 576 & 10.4 \\
\hline 3 & 0.35 & 253 & 23.7 \\
\hline
\end{tabular}

Thus, multiple administrations can raise the $\mathrm{C}_{\min }$. We note that these therapeutic indices are much smaller than the simple local TI metric outlined in Table 4. The metric in Table 4 reflects the therapeutic index defined with respect to achieving a lung $\mathrm{C}_{\max }$ greater than or equal to the $\mathrm{EC}_{90}$; clearly, more drug is required and kinetic considerations must be made to maintain concentrations greater than $\mathrm{EC}_{90}$ at all times.

\section{Discussion}

Fully one year into the COVID-19 pandemic, a dearth of effective antiviral treatments persists [69]. Drug repurposing is a promising avenue for rapidly advancing well-characterized and affordable treatments to market and has already been pursued extensively in COVID-19. Consequently, the in vitro activity of many drugs against SARS-CoV-2 has been demonstrated in the literature [70]. Many of these candidates have advanced to clinical trials in COVID-19 [71]. However, so far this has translated to limited success in the clinic.

In this work, we hypothesized that a major obstacle to successful treatment of COVID-19 is a lack of a therapeutic window. In Table 2, we show that many antiviral COVID-19 repurposing candidates do not achieve therapeutic concentrations at the target site upon systemic administration at the MTD. To address this challenge, we have described and implemented an efficient screening and validation process for repurposing clinically tested drugs for the pulmonary route of administration. Our rapid computational screen is designed to allow candidate prioritization based on publicly available in vitro efficacy and clinical tolerability data. This method focuses on maximizing the therapeutic index for COVID-19 via the pulmonary route, which we and others have identified as a key determinant of success for repurposed drugs [13].

An elegant solution to the problem of a narrow therapeutic window after systemic administration is to deliver drug directly to the active site, which in the case of COVID-19 therapeutics is the lung. Our work here shows that for this set of clinically characterized repurposing candidates, systemic toxicity will be dramatically reduced for nebulized or inhaled formulations compared to oral or intravenous administration, allowing therapeutic concentrations to be achieved in the lungs. For most of these drugs, we also demonstrate that the known inhaled or nebulized tolerated dose is likely to produce a $\mathrm{C}_{\max }$ in the lungs in excess of the in vitro $\mathrm{EC}_{90}$. 
medRxiv preprint doi: https://doi.org/10.1101/2021.03.11.21253375; this version posted March 12, 2021. The copyright holder for this preprint (which was not certified by peer review) is the author/funder, who has granted medRxiv a license to display the preprint in perpetuity.

It is made available under a CC-BY-NC 4.0 International license .

Finally, we demonstrate a lightweight in vitro-in vivo translational modeling framework to validate drug repurposing candidates for therapeutic inhalation in COVID-19. This approach allows drug selection with confidence that a therapeutic window is available and supports further dose and schedule optimization. Our work confirms that nebulized ribavirin is a promising candidate for COVID-19 therapy and demonstrates that a BID or TID schedule is suitable for achieving sustained therapeutic concentrations without inducing local or systemic toxicity.

\section{References}

1. Information on COVID-19 Treatment, Prevention and Research. In: COVID-19 Treatment Guidelines [Internet]. [cited 10 Mar 2021]. Available:

https://www.covid19treatmentguidelines.nih.gov/

2. Anti-SARS-CoV-2 Monoclonal Antibodies. In: COVID-19 Treatment Guidelines [Internet]. [cited 10 Mar 2021]. Available:

https://www.covid19treatmentguidelines.nih.gov/anti-sars-cov-2-antibody-products/antisars-cov-2-monoclonal-antibodies/

3. Therapeutic Drug Repurposing, Repositioning and Rescue Part III: Market exclusivity using Intellectual Property and regulatory pathways - Drug Discovery World (DDW). [cited 10 Mar 2021]. Available: https://www.ddw-online.com/therapeutic-drugrepurposing-repositioning-and-rescue-part-iii-market-exclusivity-using-intellectualproperty-and-regulatory-pathways-1239-201508/

4. Breckenridge A, Jacob R. Overcoming the legal and regulatory barriers to drug repurposing. Nature Reviews Drug Discovery. 2019;18: 1-2. doi:10.1038/nrd.2018.92

5. Kong R, Yang G, Xue R, Liu M, Wang F, Hu J, et al. COVID-19 Docking Server: An interactive server for docking small molecules, peptides and antibodies against potential targets of COVID-19. arXiv:200300163 [q-bio]. 2020 [cited 1 May 2020]. Available: http://arxiv.org/abs/2003.00163

6. Wang J. Fast Identification of Possible Drug Treatment of Coronavirus Disease-19 (COVID-19) through Computational Drug Repurposing Study. J Chem Inf Model. 2020;60: 3277-3286. doi:10.1021/acs.jcim.0c00179

7. Asai A, Konno M, Ozaki M, Otsuka C, Vecchione A, Arai T, et al. COVID-19 Drug Discovery Using Intensive Approaches. International Journal of Molecular Sciences. 2020;21: 2839. doi:10.3390/ijms21082839

8. Zhou Y, Hou Y, Shen J, Huang Y, Martin W, Cheng F. Network-based drug repurposing for novel coronavirus 2019-nCoV/SARS-CoV-2. Cell Discovery. 2020;6: 1-18. doi:10.1038/s41421-020-0153-3

9. McCreary EK, Angus DC. Efficacy of Remdesivir in COVID-19. JAMA. 2020;324: 1041. doi:10.1001/jama.2020.16337 
medRxiv preprint doi: https://doi.org/10.1101/2021.03.11.21253375; this version posted March 12, 2021. The copyright holder for this preprint (which was not certified by peer review) is the author/funder, who has granted medRxiv a license to display the preprint in perpetuity. It is made available under a CC-BY-NC 4.0 International license .

10. Cavalcanti AB, Zampieri FG, Rosa RG, Azevedo LCP, Veiga VC, Avezum A, et al. Hydroxychloroquine with or without Azithromycin in Mild-to-Moderate Covid-19. N Engl J Med. 2020;383: 2041-2052. doi:10.1056/NEJMoa2019014

11. Cao B, Wang Y, Wen D, Liu W, Wang J, Fan G, et al. A Trial of Lopinavir-Ritonavir in Adults Hospitalized with Severe Covid-19. N Engl J Med. 2020;382: 1787-1799. doi:10.1056/NEJMoa2001282

12. Ivermectin. In: COVID-19 Treatment Guidelines [Internet]. [cited 10 Mar 2021]. Available: https://www.covid19treatmentguidelines.nih.gov/antiviral-therapy/ivermectin/

13. Mercorelli B, Palù G, Loregian A. Drug Repurposing for Viral Infectious Diseases: How Far Are We? Trends Microbiol. 2018;26: 865-876. doi:10.1016/j.tim.2018.04.004

14. Basu S, Chakravarty A. From SARS-CoV-2 infection to COVID-19 disease: a proposed mechanism for viral spread to the lower airway based on in silico estimation of virion flow rates. medRxiv. 2020; 2020.12.19.20248544. doi:10.1101/2020.12.19.20248544

15. McKimm-Breschkin JL, Jiang S, Hui DS, Beigel JH, Govorkova EA, Lee N. Prevention and treatment of respiratory viral infections: Presentations on antivirals, traditional therapies and host-directed interventions at the 5th ISIRV Antiviral Group conference. Antiviral Res. 2018;149: 118-142. doi:10.1016/j.antiviral.2017.11.013

16. Lexmond A, Forbes B. Drug Delivery Devices for Inhaled Medicines. Handb Exp Pharmacol. 2017;237: 265-280. doi:10.1007/164_2016_67

17. Zhou QT, Leung SSY, Tang P, Parumasivam T, Loh ZH, Chan H-K. Inhaled formulations and pulmonary drug delivery systems for respiratory infections. Adv Drug Deliv Rev. 2015;85: 83-99. doi:10.1016/j.addr.2014.10.022

18. Sarcinelli MA, Martins da Silva T, Artico Silva AD, Ferreira de Carvalho Patricio B, Mendes de Paiva FC, Santos de Lima R, et al. The pulmonary route as a way to drug repositioning in COVID-19 therapy. J Drug Deliv Sci Technol. 2021;63: 102430. doi:10.1016/j.jddst.2021.102430

19. Arshad U, Pertinez H, Box H, Tatham L, Rajoli RKR, Curley P, et al. Prioritization of AntiSARS-Cov-2 Drug Repurposing Opportunities Based on Plasma and Target Site Concentrations Derived from their Established Human Pharmacokinetics. Clin Pharmacol Ther. 2020;108: 775-790. doi:10.1002/cpt.1909

20. Perelson AS, Deeks SG. Drug Effectiveness Explained: The Mathematics of Antiviral Agents for HIV. Sci Transl Med. 2011;3: 91ps30. doi:10.1126/scitranslmed.3002656

21. Fröhlich E, Mercuri A, Wu S, Salar-Behzadi S. Measurements of Deposition, Lung Surface Area and Lung Fluid for Simulation of Inhaled Compounds. Front Pharmacol. 2016;7. doi:10.3389/fphar.2016.00181 
medRxiv preprint doi: https://doi.org/10.1101/2021.03.11.21253375; this version posted March 12, 2021. The copyright holder for this preprint (which was not certified by peer review) is the author/funder, who has granted medRxiv a license to display the preprint in perpetuity. It is made available under a CC-BY-NC 4.0 International license .

22. Patton JS, Fishburn CS, Weers JG. The Lungs as a Portal of Entry for Systemic Drug Delivery. Proc Am Thorac Soc. 2004;1: 338-344. doi:10.1513/pats.200409-049TA

23. Longest PW, Bass K, Dutta R, Rani V, Thomas ML, El-Achwah A, et al. Use of computational fluid dynamics deposition modeling in respiratory drug delivery. Expert Opin Drug Deliv. 2019;16: 7-26. doi:10.1080/17425247.2019.1551875

24. VIRAZOLE® (Ribavirin for Inhalation Solution, USP). [cited 26 Feb 2021]. Available: https://dailymed.nlm.nih.gov/dailymed/fda/fdaDrugXsl.cfm?setid=adf16e64-345f-469ab987-3fbdd17e0ac2\&type=display

25. Characterization of Ribavirin Aerosol With Small Particle Aerosol Generator and Vibrating Mesh Micropump Aerosol Technologies | Respiratory Care. [cited 26 Feb 2021]. Available: http://rc.rcjournal.com/content/61/5/577.short

26. Stevens N, Prime D. How Particle Size Changes Lung Deposition: A Physical Modeller's Perspective. 2015; 4.

27. Borczuk AC, Salvatore SP, Seshan SV, Patel SS, Bussel JB, Mostyka M, et al. COVID-19 pulmonary pathology: a multi-institutional autopsy cohort from Italy and New York City. Modern Pathology. 2020;33: 2156-2168. doi:10.1038/s41379-020-00661-1

28. Stockmann C, Roberts JK, Yellepeddi VK, Sherwin CMT. Clinical Pharmacokinetics of Inhaled Antimicrobials. Clin Pharmacokinet. 2015;54: 473-492. doi:10.1007/s40262-0150250-X

29. Connor J. Ribavirin Pharmacokinetics. Pediatric Infectious Disease Journal. 1990;9: S91S92.

30. Gaohua L, Wedagedera J, Small B, Almond L, Romero K, Hermann D, et al. Development of a Multicompartment Permeability-Limited Lung PBPK Model and Its Application in Predicting Pulmonary Pharmacokinetics of Antituberculosis Drugs: Lung PBPK Model. CPT Pharmacometrics Syst Pharmacol. 2015;4: 605-613. doi:10.1002/psp4.12034

31. Tronde A. Pulmonary Drug Absorption: In vitro and in vivo investigations of drug absorption across the lung barrier and its relation to drug physicochemical properties. Comprehensive Summaries of Uppsala Dissertations from the Faculty of Pharmacy. 2002.

32. Reddy MB, Morcos PN, Pogam SL, Ou Y, Frank K, Lave T, et al. Pharmacokinetic/Pharmacodynamic Predictors of Clinical Potency for Hepatitis C Virus Nonnucleoside Polymerase and Protease Inhibitors. Antimicrobial Agents and Chemotherapy. 2012;56: 3144-3156. doi:10.1128/AAC.06283-11

33. Gupta P, Kamath AV, Park S, Chiu H, Lutman J, Maia M, et al. Preclinical pharmacokinetics of MHAA4549A, a human monoclonal antibody to influenza A virus, and the prediction of its efficacious clinical dose for the treatment of patients hospitalized with influenza A. MAbs. 2016;8: 991-997. doi:10.1080/19420862.2016.1167294 
medRxiv preprint doi: https://doi.org/10.1101/2021.03.11.21253375; this version posted March 12, 2021. The copyright holder for this preprint (which was not certified by peer review) is the author/funder, who has granted medRxiv a license to display the preprint in perpetuity.

It is made available under a CC-BY-NC 4.0 International license .

34. Wistrand-Yuen E, Knopp M, Hjort K, Koskiniemi S, Berg OG, Andersson DI. Evolution of high-level resistance during low-level antibiotic exposure. Nature Communications. 2018;9: 1599. doi:10.1038/s41467-018-04059-1

35. Arshad U, Pertinez H, Box H, Tatham L, Rajoli RK, Curley P, et al. Prioritisation of potential anti-SARS-CoV-2 drug repurposing opportunities based on ability to achieve adequate plasma and target site concentrations derived from their established human pharmacokinetics. medRxiv. 2020; 2020.04.16.20068379.

doi:10.1101/2020.04.16.20068379

36. Bayer Healthcare. Trasylol (aprotinin injection). FDA; 2006.

37. Bojkova D, McGreig JE, McLaughlin K-M, Masterson SG, Widera M, Krähling V, et al. SARS-CoV-2 and SARS-CoV differ in their cell tropism and drug sensitivity profiles. Microbiology; 2020 Apr. doi:10.1101/2020.04.03.024257

38. Foipan Tablets $100 \mathrm{mg}$ <Camostat mesilate tablets>. 2009.

39. Hoffmann M, Kleine-Weber H, Schroeder S, Krüger N, Herrler T, Erichsen S, et al. SARSCoV-2 Cell Entry Depends on ACE2 and TMPRSS2 and Is Blocked by a Clinically Proven Protease Inhibitor. Cell. 2020;181: 271-280.e8. doi:10.1016/j.cell.2020.02.052

40. Iroko Pharmaceuticals. Indocin (Indomethacin) Oral Suspension. FDA; 2008. Available: https://www.accessdata.fda.gov/drugsatfda_docs/label/2009/018332s032lbl.pdf

41. Xu T, Gao X, Wu Z, Selinger DW, Zhou Z. Indomethacin has a potent antiviral activity against SARS CoV-2 in vitro and canine coronavirus in vivo. Microbiology; 2020 Apr. doi:10.1101/2020.04.01.017624

42. Cazaubon Y, Venisse N, Mimoz O, Maire P, Ducher M, Bourguignon L, et al. Population pharmacokinetics of teicoplanin administered by subcutaneous or intravenous route and simulation of optimal loading dose regimen. Journal of Antimicrobial Chemotherapy. 2017;72: 2804-2812. doi:10.1093/jac/dkx242

43. Zhang J, Ma X, Yu F, Liu J, Zou F, Pan T, et al. Teicoplanin potently blocks the cell entry of 2019-nCoV. bioRxiv. 2020; 2020.02.05.935387. doi:10.1101/2020.02.05.935387

44. Niclosamide a new chemotherapy agent? Pharmacokinetics of the potential anticancer drug in a patient cohort of the NIKOLO trial. | Journal of Clinical Oncology. [cited 26 Feb 2021]. Available: https://ascopubs.org/doi/abs/10.1200/JCO.2018.36.15_suppl.e14536

45. Gassen NC, Papies J, Bajaj T, Dethloff F, Emanuel J, Weckmann K, et al. Analysis of SARS-CoV-2-controlled autophagy reveals spermidine, MK-2206, and niclosamide as putative antiviral therapeutics. Microbiology; 2020 Apr. doi:10.1101/2020.04.15.997254

46. ZITHROMAX (azithromycin) $250 \mathrm{mg}$ and $500 \mathrm{mg}$ Tablets and Oral Suspension. : 25. 
medRxiv preprint doi: https://doi.org/10.1101/2021.03.11.21253375; this version posted March 12, 2021. The copyright holder for this preprint (which was not certified by peer review) is the author/funder, who has granted medRxiv a license to display the preprint in perpetuity. It is made available under a CC-BY-NC 4.0 International license .

47. Touret F, Gilles M, Barral K, Nougairède A, van Helden J, Decroly E, et al. In vitro screening of a FDA approved chemical library reveals potential inhibitors of SARS-CoV-2 replication. Scientific Reports. 2020;10: 13093. doi:10.1038/s41598-020-70143-6

48. Copegus (ribavirin) Tablets. FDA; 2011. Available: https://www.accessdata.fda.gov/drugsatfda_docs/label/2011/021511s023lbl.pdf

49. Aggrenox (aspirin/extended-release dipyridamole) capsules. FDA; 2015. Available: https://www.accessdata.fda.gov/drugsatfda_docs/label/2015/020884s035lbl.pdf

50. Liu X, Li Z, Liu S, Sun J, Chen Z, Jiang M, et al. Potential therapeutic effects of dipyridamole in the severely ill patients with COVID-19. Acta Pharm Sin B. 2020;10: 1205-1215. doi:10.1016/j.apsb.2020.04.008

51. Levy JH, Bailey JM, Salmenperä M. Pharmacokinetics of aprotinin in preoperative cardiac surgical patients. Anesthesiology. 1994;80: 1013-1018. doi:10.1097/00000542-19940500000010

52. Alván G, Orme M, Bertilsson L, Ekstrand R, Palmér L. Pharmacokinetics of indomethacin. Clin Pharmacol Ther. 1975;18: 364-373. doi:10.1002/cpt1975183364

53. Wilson AP. Clinical pharmacokinetics of teicoplanin. Clin Pharmacokinet. 2000;39: 167183. doi:10.2165/00003088-200039030-00001

54. Singlas E. [Clinical pharmacokinetics of azithromycin]. Pathol Biol (Paris). 1995;43: 505511.

55. Glue P. The clinical pharmacology of ribavirin. Semin Liver Dis. 1999;19 Suppl 1: 17-24.

56. Bjornsson TD, Mahony C. Clinical pharmacokinetics of dipyridamole. Thromb Res Suppl. 1983;4: 93-104. doi:10.1016/0049-3848(83)90364-х

57. Qiu W, Suarez S. Clinical Pharmacology Review. FDA; 2007. Available: https://www.fda.gov/media/71478/download

58. Xu J, Nave R, Lahu G, Derom E, Derendorf H. Population pharmacokinetics and pharmacodynamics of inhaled ciclesonide and fluticasone propionate in patients with persistent asthma. J Clin Pharmacol. 2010;50: 1118-1127. doi:10.1177/0091270009354994

59. Matsuyama S, Kawase M, Nao N, Shirato K, Ujike M, Kamitani W, et al. The inhaled corticosteroid ciclesonide blocks coronavirus RNA replication by targeting viral NSP15. bioRxiv. 2020; 2020.03.11.987016. doi:10.1101/2020.03.11.987016

60. Metered dose inhaler containing aprotinin, a protease inhibitor, as a drug against influenza. [cited 26 Feb 2021]. Available: https://www.longdom.org/proceedings/metered-doseinhaler-containing-aprotinin-a-protease-inhibitor-as-a-drug-against-influenza-5674.html 
medRxiv preprint doi: https://doi.org/10.1101/2021.03.11.21253375; this version posted March 12, 2021. The copyright holder for this preprint (which was not certified by peer review) is the author/funder, who has granted medRxiv a license to display the preprint in perpetuity. It is made available under a CC-BY-NC 4.0 International license .

61. Rowe SM, Reeves G, Hathorne H, Solomon GM, Abbi S, Renard D, et al. Reduced Sodium Transport With Nasal Administration of the Prostasin Inhibitor Camostat in Subjects With Cystic Fibrosis. Chest. 2013;144: 200-207. doi:10.1378/chest.12-2431

62. Wang M, Wisniewski A, Pavord I, Knox A, Tattersfield A. Comparison of three inhaled non-steroidal anti-inflammatory drugs on the airway response to sodium metabisulphite and adenosine 5'-monophosphate challenge in asthma. Thorax. 1996;51: 799-804. doi:10.1136/thx.51.8.799

63. Neupharma Srl. An Open-label, Dose-escalation Study to Evaluate the Pharmacokinetics of Inhaled Teicoplanin in Cystic Fibrosis Patients. clinicaltrials.gov; 2020 Dec. Report No.: study/NCT04176328. Available: https://clinicaltrials.gov/ct2/show/study/NCT04176328

64. therapeutics U. UNION therapeutics A/S completes dosing of healthy volunteers with UNI911 (inhaled niclosamide) for COVID-19. [cited 26 Feb 2021]. Available:

https://www.prnewswire.com/news-releases/union-therapeutics-as-completes-dosing-ofhealthy-volunteers-with-uni911-inhaled-niclosamide-for-covid-19-301117470.html

65. Maneshi A, Modaresi MR, Khalili H, Shojae L, Faghihi T. Nebulized Azithromycin Versus Oral Azithromycin as Anti-Inflammatory Therapy in Children with Cystic Fibrosis: A Prospective Randomized Open-Label Trial. In: Iranian Journal of Pediatrics [Internet]. 31 Dec 2019 [cited 26 Feb 2021]. Available: https://sites.kowsarpub.com/ijp/articles/96977.html\#abstract

66. Ghosh S, Champlin RE, Englund J, Giralt SA, Rolston K, Raad I, et al. Respiratory syncytial virus upper respiratory tract illnesses in adult blood and marrow transplant recipients: combination therapy with aerosolized ribavirin and intravenous immunoglobulin. Bone Marrow Transplant. 2000;25: 751-755. doi:10.1038/sj.bmt. 1702228

67. Cushley MJ, Tallant N, Holgate ST. The effect of dipyridamole on histamine- and adenosine-induced bronchoconstriction in normal and asthmatic subjects. Eur J Respir Dis. 1985;67: 185-192.

68. Alvesco (ciclesonide) Inhalation Aerosol $80 \mathrm{mcg}, 160 \mathrm{mcg}$ for oral inhalation only. FDA; 2006. Available: https://www.accessdata.fda.gov/drugsatfda_docs/label/2012/021658s006lbl.pdf

69. Research C for DE and. Coronavirus Treatment Acceleration Program (CTAP). FDA. 2021 [cited 26 Feb 2021]. Available: https://www.fda.gov/drugs/coronavirus-covid-19drugs/coronavirus-treatment-acceleration-program-ctap

70. Weston S, Coleman CM, Haupt R, Logue J, Matthews K, Li Y, et al. Broad Anticoronavirus Activity of Food and Drug Administration-Approved Drugs against SARSCoV-2 In Vitro and SARS-CoV In Vivo. J Virol. 2020;94. doi:10.1128/JVI.01218-20

71. Singh TU, Parida S, Lingaraju MC, Kesavan M, Kumar D, Singh RK. Drug repurposing approach to fight COVID-19. Pharmacol Rep. 2020; 1-30. doi:10.1007/s43440-020-001556 
medRxiv preprint doi: https://doi.org/10.1101/2021.03.11.21253375; this version posted March 12, 2021. The copyright holder for this preprint (which was not certified by peer review) is the author/funder, who has granted medRxiv a license to display the preprint in perpetuity.

$$
\text { It is made available under a CC-BY-NC } 4.0 \text { International license. }
$$


medRxiv preprint doi: https://doi.org/10.1101/2021.03.11.21253375; this version posted March 12, 2021. The copyright holder for this preprint (which was not certified by peer review) is the author/funder, who has granted medRxiv a license to display the preprint in perpetuity. It is made available under a CC-BY-NC 4.0 International license .

\section{Figures}

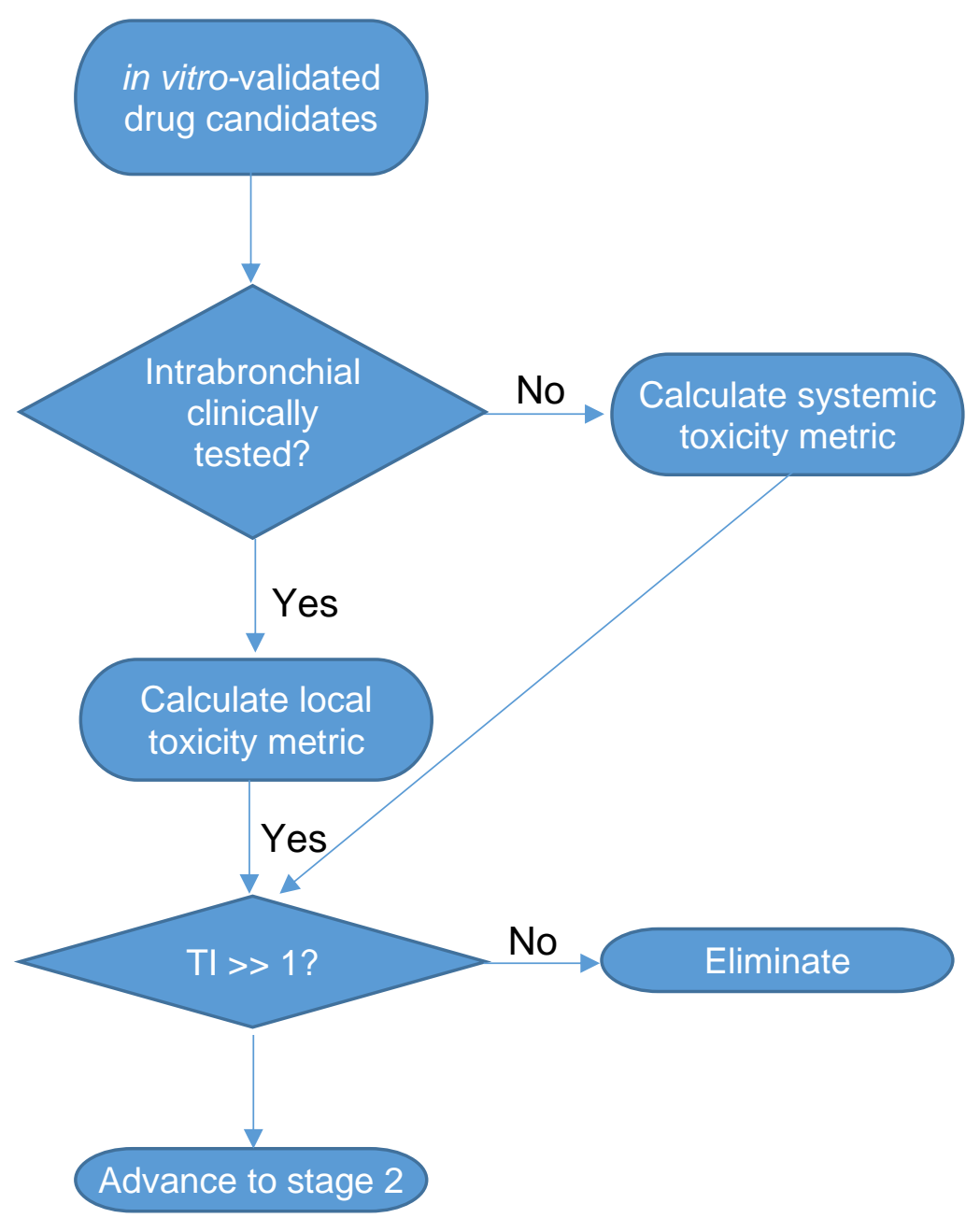

Figure 1. Flow-chart for rapid first-pass screen of in vitro-validated drug candidates for repurposing in the inhaled setting. A therapeutic index is calculated based on local or systemic toxicity and used to select drugs expected to have a wide therapeutic window after inhalation. 
medRxiv preprint doi: https://doi.org/10.1101/2021.03.11.21253375; this version posted March 12, 2021. The copyright holder for this preprint (which was not certified by peer review) is the author/funder, who has granted medRxiv a license to display the preprint in perpetuity.

It is made available under a CC-BY-NC 4.0 International license .

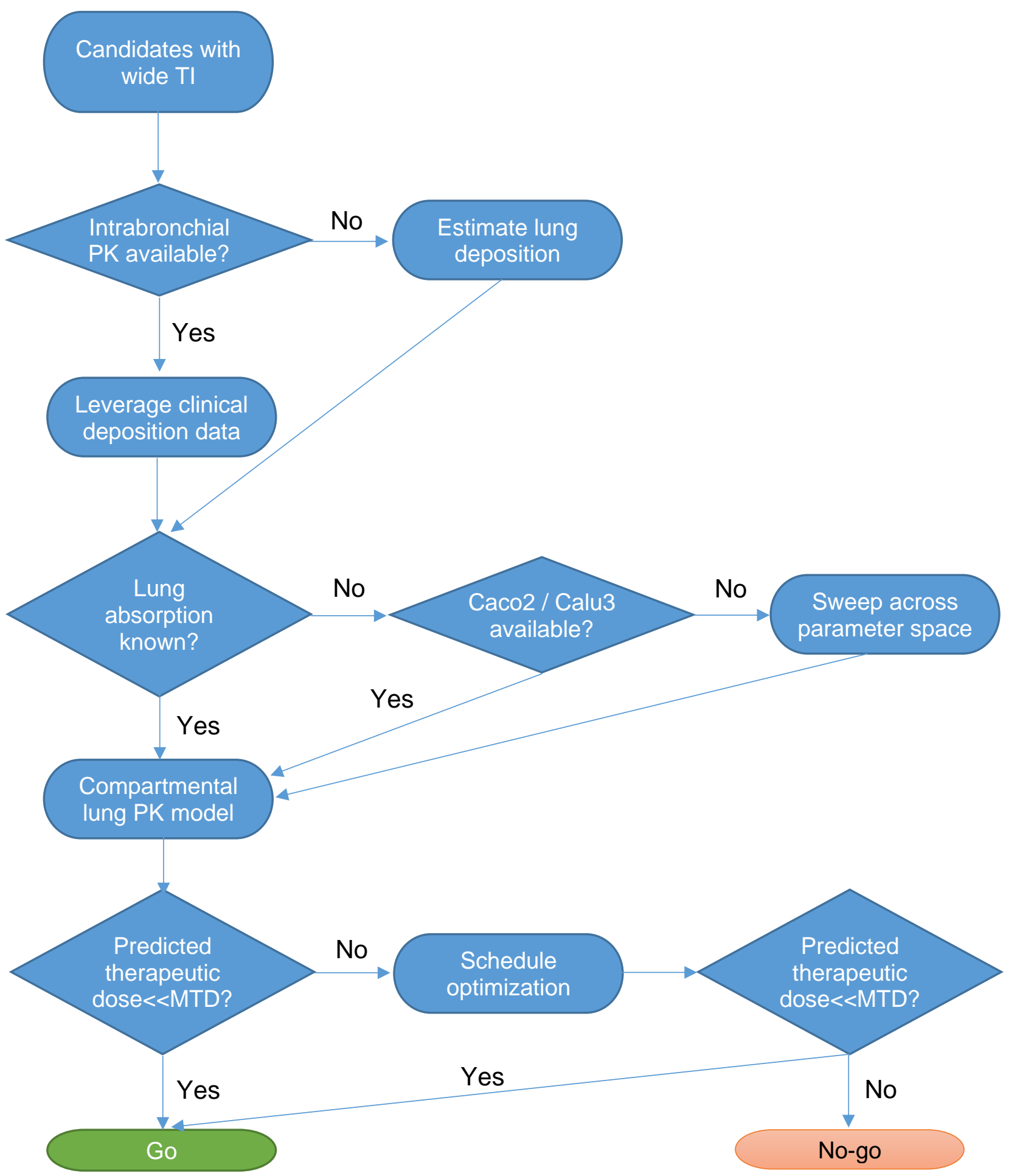

Figure 2. Flowchart outlining decision process based on a refined TI calculation. Lung deposition and absorption are estimated for the drug of interest to allow model-based prediction of the therapeutic dose. Drugs suitable for repurposing will have a therapeutic dose that is significantly less than the maximum tolerated dose. 
medRxiv preprint doi: https://doi.org/10.1101/2021.03.11.21253375; this version posted March 12, 2021. The copyright holder for this preprint (which was not certified by peer review) is the author/funder, who has granted medRxiv a license to display the preprint in perpetuity.

A
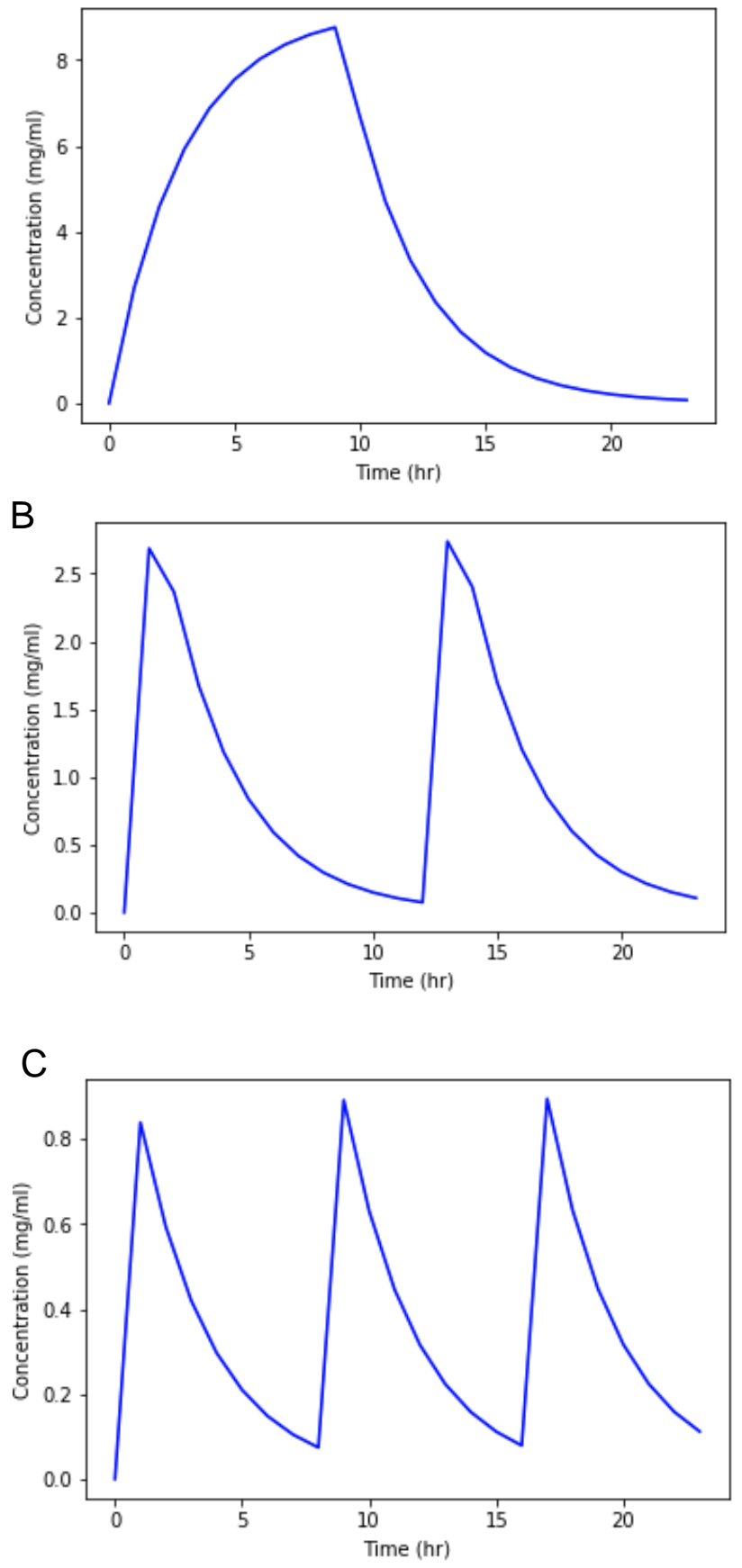

Figure 3. Model-predicted lung pharmacokinetics for nebulized ribavirin. Predicted lung concentration-time profiles for A) once-daily, B) twice-daily (BID), or C) three times daily (TID) administration by SPAG-2 nebulizer. Nebulization duration is optimized such that the minimum lung concentration $\left(\mathrm{C}_{\min }\right)$ is greater than or equal to the $\mathrm{EC}_{90}$ for ribavirin $(0.074 \mathrm{mg} / \mathrm{mL})$. 